\title{
Electronic Visualisation and the Arts (EVA 2010)
}

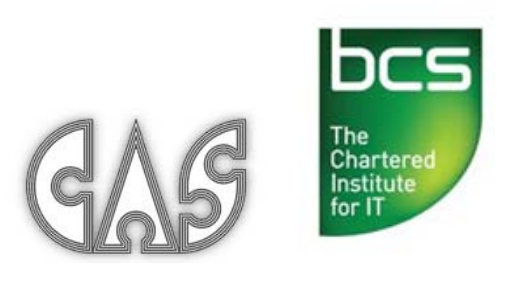

London, UK

$$
5 \text { - } 7 \text { July } 2010
$$

Editors:

\author{
Alan Seal \\ Jonathan P. Bowen
}

$\mathrm{Kia} \mathrm{Ng}$ 


\section{Abstract}

Electronic Visualisation and the Arts London 2010 (EVA 2010) is co-sponsored by the Computer Arts Society and BCS, The Chartered Institute for IT, of which the Computer Arts Society is a specialist group. Since 1992, the EVA conference series has established itself as a natural home from which to explore the richly interdisciplinary and constantly evolving world of digital visualisation. Nothing illustrates this more than the great scope, depth and diversity of the papers contained within this year's Proceedings.

The latest research in digital arts and new media are explored, with contributors ranging from established scholars to the new generation of research students who will lead the field tomorrow. Conference papers cover reconstructive archaeology, virtual museology, digital arts concepts and practice, immersive environments, and digital performance and music. 


\section{Editors}

Alan Seal has recently worked as Head of Records and Collections Services in the Victoria and Albert Museum where he was responsible for the photographic services and archive in the museum and the automation and digitisation of the collections. He was previously head of collections management in the National Art Library in the V\&A. A librarian by training, he is particularly interested in user interfaces and online public access systems, both textual and multi-media. He has undertaken research into bibliographic standards in information systems and online library catalogues during a period at the Centre for Catalogue Research at the University of Bath.

Jonathan P. Bowen is a computer scientist and Chair of Museophile Limited, a museum and IT consultancy company, with the aim of helping museums online, especially in the areas of virtual communities, wikis, web accessibility, and personalisation. http://jpbowen.googlepages.com

Kia Ng is Director of the Interdisciplinary Centre for Scientific Research in Music at the University of Leeds. Kia is involved in several research domains including gestural interfaces, interactive multimedia, computer vision, document imaging and computer music, in collaboration with many European and international organisations and individuals in the field. Large-scale projects include i-Maestro on technology-enhanced learning (coordinator), CASPAR on digital preservation and AXMEDIS on crossmedia (principle investigator) with over 20M Euro research funding. Kia has more than 150 publications and presented talks in over 30 countries including keynotes and invited lectures in Canada, China, France, Germany, Japan, UK and the USA. www.kcng.org 


\section{Papers:}

\section{Session 1: Electronic arts}

Alicia Bastos Discovering digital cultural capital in London's events of art and technology: reviewing the last decade $\quad$ http://dx.doi.org/10.14236/ewic/EVA2010.1

Jeremy Pilcher Legal networks: visualising the violence of the law http://dx.doi.org/10.14236/ewic/EVA2010.2

Almila Akdag Salah The online potential of art creation and dissemination: DeviantArt as the next art venue http://dx.doi.org/10.14236/ewic/EVA2010.3

\section{Keynote paper}

Peter Cochrane Beyond seeing is believing http://dx.doi.org/10.14236/ewic/EVA2010.4

Session 2: Data, art and time

Alex McLean, et al. Visualisation of live code $\quad$ http://dx.doi.org/10.14236/ewic/EVA2010.5

Pedro Rebelo and Robert King Anticipation in networked musical performance http://dx.doi.org/10.14236/ewic/EVA2010.6

Ernest Edmonds $\quad$ Beyond abstract film: constructivist digital time http://dx.doi.org/10.14236/ewic/EVA2010.7

\section{Keynote paper}

Seb Chan Tracking interactions: new ways of finding value in the use of museums http://dx.doi.org/10.14236/ewic/EVA2010.8 


\section{Session 3: The digital museum}

Blanca Acuña A new media approach: visualisation of a digital exhibition. Research on representation and design of cultural interfaces http://dx.doi.org/10.14236/ewic/EVA2010.9

Sam Hinton and Mitchell Whitelaw Exploring the digital commons: an approach to the visualisation of large heritage datasets $\quad \underline{\text { http://dx.doi.org/10.14236/ewic/EVA2010.10 }}$

Arden Kirkland, et al. Context for costumes: faceted access to historic costumes http://dx.doi.org/10.14236/ewic/EVA2010.11

\section{Session 4: Digital museum 2}

Theopisti Stylianou-Lambert and Elena Stylianou A third space: reconsidering issues of neutrality and accessibility in the virtual art museum $\quad$ http://dx.doi.org/10.14236/ewic/EVA2010.12

Yvonne Hellin-Hobbs The constructivist museum and the web http://dx.doi.org/10.14236/ewic/EVA2010.13

Ingrid Beazley, et al. Dulwich OnView: an art museum-based virtual community generated by the local community $\quad$ http://dx.doi.org/10.14236/ewic/EVA2010.14

Steven Snyder and Karen Elinich Augmented reality for interpretive and experiential learning http://dx.doi.org/10.14236/ewic/EVA2010.15

Luciana Bordoni and Giuseppe Moscara A system for the investigation of cracks http://dx.doi.org/10.14236/ewic/EVA2010.16

\section{Session 5: Art through evolutionary computation}

Dew Harrison Exploring Duchampian and Darwinian ideas through interactive means http://dx.doi.org/10.14236/ewic/EVA2010.17

Barry Dean and Ian Parmee Integration of user-centred evolutionary computation with digital visualisation http://dx.doi.org/10.14236/ewic/EVA2010.18

Mohammad A Yaghan The evolution of architectural forms through computer visualisation: muqarnas example $\quad$ http://dx.doi.org/10.14236/ewic/EVA2010.19 
ArefeDalvandi, et al. Exploring Persian rug design using a computational evolutionary approach http://dx.doi.org/10.14236/ewic/EVA2010.20

\section{Session 6: Digital art issues}

Murat Germen Photography as a tool of alienation: Aura http://dx.doi.org/10.14236/ewic/EVA2010.21

A Hoeben Using a projected Trompe L'Oeil to highlight a church interior from the inside http://dx.doi.org/10.14236/ewic/EVA2010.22

R Collmann and A Borda

Simulated-3D visualisation of artefacts using a portable

electromechanical object rig http://dx.doi.org/10.14236/ewic/EVA2010.23

Lindsay MacDonald The limits of resolution http://dx.doi.org/10.14236/ewic/EVA2010.24

\section{Keynote paper}

David Giaretta Digital preservation: terminology, techniques, testing and trust http://dx.doi.org/10.14236/ewic/EVA2010.25

\section{Session 7: Digital art issues}

Gregory Sporton Creative identity theft: issues for artists in collaborative online environments http://dx.doi.org/10.14236/ewic/EVA2010.26

Annamaria Carusi, et al.Are digital picturings representations?

http://dx.doi.org/10.14236/ewic/EVA2010.27

\section{Session 8: Electronic resources for the public}

Jules Moloney Mixed reality and curatorial design: from existing practice to the nomad_tech museum http://dx.doi.org/10.14236/ewic/EVA2010.28

Lisa Dieckmann, et al. Meta-Image - a collaborative environment for the image discourse 
http://dx.doi.org/10.14236/ewic/EVA2010.29

Karol Kwiatek and Martin Woolner. Let me understand the poetry: embedding interactive storytelling within panoramic virtual environments http://dx.doi.org/10.14236/ewic/EVA2010.30

Sylvia Grace Borda Digital image archives as public artwork and community engagement http://dx.doi.org/10.14236/ewic/EVA2010.31

\section{Session 9: Music and art}

Matt Benatan, et al. MiMic: a motion control interface for music http://dx.doi.org/10.14236/ewic/EVA2010.32

Martha Gabriel Voice interfaces in electronic art http://dx.doi.org/10.14236/ewic/EVA2010.33

Kia Ng and Bee Ong Interactive multimedia rocks for geology http://dx.doi.org/10.14236/ewic/EVA2010.34

Lisa Dalhuijsen and Lieven van Velthoven MusicalNodes, the visual music library http://dx.doi.org/10.14236/ewic/EVA2010.35

\section{Keynote paper}

Alan Read The ceramic age: a gloss on depth http://dx.doi.org/10.14236/ewic/EVA2010.36

\section{Session 10: Digital performance}

Richard Hoadley Implementation and development of sculptural interfaces for digital performance of music through embodied expression http://dx.doi.org/10.14236/ewic/EVA2010.37

Sam Bailey, et al. Eye.Breathe.Music: creating music through minimal movement http://dx.doi.org/10.14236/ewic/EVA2010.38

\section{Session 11: Digital arts practice}


David R. Burns The valuation of emerging media arts in the age of digital reproduction http://dx.doi.org/10.14236/ewic/EVA2010.39

Chris Cornish Media archaeology in art practice $\quad$ http://dx.doi.org/10.14236/ewic/EVA2010.40

Rui Filipe Antunes and Frederic Fol Leymarie Virtual worlds as art practice: EvoArt methodologies http://dx.doi.org/10.14236/ewic/EVA2010.41

Anne James and Dai Nagasaka Architectonic influences of multimedia and their spatial significance http://dx.doi.org/10.14236/ewic/EVA2010.42

\section{Keynote paper}

Oliver Grau Renewing knowledge structures for Media Art http://dx.doi.org/10.14236/ewic/EVA2010.43

\section{Session 12: Digital perceptions}

Steve DiPaola Face, portrait, mask - using a parameterised system to explore synthetic face space http://dx.doi.org/10.14236/ewic/EVA2010.44

Fernanda D'Agostino, et al. Motion Studies: an art and science collaboration http://dx.doi.org/10.14236/ewic/EVA2010.45

Julie Innes Capturing worlds $\quad$ http://dx.doi.org/10.14236/ewic/EVA2010.46

\section{Session 13: Art in the digital age}

Lisa Newman Flesh for fantasy: the future of sadomasochism and performance art in virtual worlds http://dx.doi.org/10.14236/ewic/EVA2010.47

Phil Hawks The relevance of traditional drawing in the digital age http://dx.doi.org/10.14236/ewic/EVA2010.48 


\section{Session 14: Digital understandings of the past}

Stephen Caffey, et al. Reconstructing the Music Hall Rotunda and Annex at Vauxhall Pleasure Gardens c. 1764 http://dx.doi.org/10.14236/ewic/EVA2010.49

Martin Crampin New light on old stone: recording and reinventing visual culture http://dx.doi.org/10.14236/ewic/EVA2010.50

\section{Session 15: Experiencing history}

Wally Smith, et al. Re-connecting visual content to place in a mobile guide for the Shrine of Remembrance http://dx.doi.org/10.14236/ewic/EVA2010.51

Stephen Boyd Davis, et al. Just in time: defining historical chronographics http://dx.doi.org/10.14236/ewic/EVA2010.52

Tony Longson Ideas and influences http://dx.doi.org/10.14236/ewic/EVA2010.53 